\title{
A Simple Computer Model for the Prediction of Chemical Shrinkage and Heat of Hydration of Sugarcane Waste Fiber Ash (SWFA)-Cement Paste
}

\author{
J. N. Mwero ${ }^{1}$ \\ 1 - Department of Civil \& Construction Engineering, University of Nairobi. \\ Johnmwero1@gmail.com
}

DOI: 10.29322/IJSRP.10.04.2020.p10067

http://dx.doi.org/10.29322/IJSRP.10.04.2020.p10067

\begin{abstract}
A computer model coded in Visual Basic and based on the chemical reaction rules of cement hydration reactions was able to predict reasonably the chemical shrinkage and heat of hydration of hydrating cement pastes containing $0-20 \%$ Sugarcane Waste Fiber Ash (SWFA), and also the 28 day compressive strength values of concrete containing $0-20 \%$ SWFA by weight of the total binder.
\end{abstract}

\subsection{INTRODUCTION AND MODEL CREATION APPROACH}

The computer model "SWFAHYD" was developed to analyze hydration of pozzolanic cement containing sugarcane waste fiber ash (SWFA) partially replacing Portland cement by weight percentages of between 0 and 20 percent, with a water binder ration of 0.53 .

It was intended to be able to predict the heat of hydration, chemical shrinkage and the strength of resulting concrete mixes made of cement pastes containing SWFA.

The steps in creation of the hydration model, together with experimental interrelations were partially based on work done by Bentz [1].

As summarized in the flow chart Figure 1, the model uses SWFA-Cement oxides from chemical analyses previously carried out in the study to calculate the primary cement phases after which it proceeds to carry out the reactions and predict the final quantities of the cement phases at the chosen age of the cement paste. For the model the chosen paste age is decided upon by the user, between 1 hour and 24 hours after mixing. From these final quantities of the cement phases, heat of hydration and chemical shrinkage are calculated. Based on the chemical shrinkage, the tensile strengths of the resulting concrete mixes are also calculated, as illustrated schematically in Figure 1.

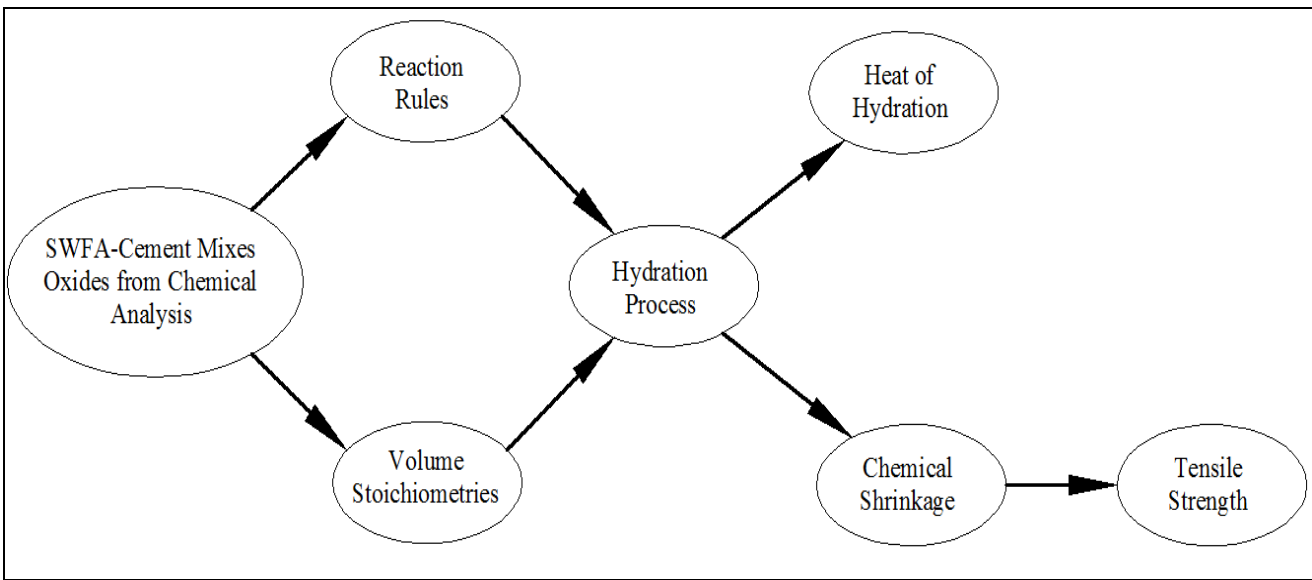

Figure 1 Flow diagram summarising the modeling program for predicting heat of hydration and chemical shrinkage of SWFACement paste, and tensile strength 
The model outputs were then compared with the corresponding laboratory results of tensile splitting, heat of hydration and chemical shrinkage. Details of the model are outlined in later sections of this document.

\section{Model Cement Phases}

12 cement phases were considered in the model, namely;

1. Tricalcium Silicate $\left(\mathrm{C}_{3} \mathrm{~S}\right)$

2. Dicalcium Silicate $\left(\mathrm{C}_{2} \mathrm{~S}\right)$

3. Tricalcium Aluminate $\left(\mathrm{C}_{3} \mathrm{~A}\right)$

4. Tetracalcium Alumino Ferrite $\left(\mathrm{C}_{4} \mathrm{AF}\right)$

5. Gypsum $\left(\mathrm{CSH}_{2}\right)$

6. Calcium Silicate Hydrate $\left(\mathrm{C}_{1.7} \mathrm{SH}_{4}\right)$

7. Ettringite $\left(\mathrm{C}_{6} \mathrm{AS}_{3} \mathrm{H}_{32}\right)$

8. Monosulfate $\left(\mathrm{C}_{4} \mathrm{ASH}_{12}\right)$

9. Hydrogarnet $\left(\mathrm{C}_{3} \mathrm{AH}_{6}\right)$

10. Calcium Hydroxide $(\mathrm{CH})$

11. Iron Hydroxide $\left(\mathrm{FH}_{3}\right)$

12. Water $(\mathrm{H})$

Table 1 summarizes properties of these initial phases [1]

Table 1 Selected properties of minerals contained in cement [1]

\begin{tabular}{|c|c|c|c|c|c|c|}
\hline Name of Mineral & $\begin{array}{l}\text { Chemists } \\
\text { Notation }\end{array}$ & Chemical Formula & $\begin{array}{l}\text { Molar } \\
\text { Mass } \\
\text { (g/mole) }\end{array}$ & $\begin{array}{l}\text { Molar } \\
\text { Volume } \\
\left(\mathrm{cm}^{3} / \mathrm{mole}\right)\end{array}$ & $\begin{array}{l}\text { Heat of } \\
\text { Formation } \\
\text { (kJ/mole) }\end{array}$ & $\begin{array}{l}\text { Density } \\
\left(\mathrm{Mg} / \mathrm{m}^{3}\right)\end{array}$ \\
\hline Tricalcium Silicate & $\mathrm{C}_{3} \mathrm{~S}$ & $3 \mathrm{CaO} . \mathrm{SiO}_{2}$ & 228.33 & 71.00 & $-2,927.82$ & 3.21 \\
\hline Dicalcium Silicate & $\mathrm{C}_{2} \mathrm{~S}$ & $2 \mathrm{CaO} . \mathrm{SiO}_{2}$ & 172.25 & 52.00 & $-2,311.60$ & 3.28 \\
\hline Tricalcium Aluminate & $\mathrm{C}_{3} \mathrm{~A}$ & $3 \mathrm{CaO} \cdot \mathrm{Al}_{2} \mathrm{O}_{3}$ & 270.20 & 89.10 & $-3,587.80$ & 3.03 \\
\hline Tetracalcium Alumino Ferrite & $\mathrm{C}_{4} \mathrm{AF}$ & $4 \mathrm{CaO} \cdot \mathrm{Al}_{2} \mathrm{O}_{3} \cdot \mathrm{Fe}_{2} \mathrm{O}_{3}$ & 485.96 & 128.00 & $-5,090.30$ & 3.73 \\
\hline Gypsum & $\mathrm{CSH}_{2}$ & $\mathrm{CaO} . \mathrm{SiO}_{2} \cdot 2 \mathrm{H}_{2} \mathrm{O}$ & 152.20 & 74.20 & $-2,022.60$ & 2.32 \\
\hline Calcium Silicate Hydrate & $\mathrm{C}_{1.7} \mathrm{SH}_{4}$ & $1.7 \mathrm{CaO} . \mathrm{SiO}_{2} .4 \mathrm{H}_{2} \mathrm{O}$ & 227.49 & 108.00 & $-3,283.00$ & 2.12 \\
\hline Calcium Hydroxide & $\mathrm{CH}$ & $\mathrm{CaO} . \mathrm{H}_{2} \mathrm{O}$ & 74.10 & 33.10 & -986.10 & 2.24 \\
\hline Ettringite & $\mathrm{C}_{6} \mathrm{AS}_{3} \mathrm{H}_{32}$ & $6 \mathrm{CaO} . \mathrm{Al}_{2} \mathrm{O}_{3} .3 \mathrm{SiO}_{2} .32 \mathrm{H}_{2} \mathrm{O}$ & $1,195.22$ & 735.00 & $-17,539.00$ & 1.70 \\
\hline Monosulfate & $\mathrm{C}_{4} \mathrm{ASH}_{12}$ & $4 \mathrm{CaO} . \mathrm{Al}_{2} \mathrm{O}_{3} \cdot \mathrm{SiO}_{2} \cdot 12 \mathrm{H}_{2} \mathrm{O}$ & 602.56 & 313.00 & $-8,778.00$ & 1.99 \\
\hline Hydrogarnet & $\mathrm{C}_{3} \mathrm{AH}_{6}$ & $3 \mathrm{CaO} . \mathrm{Al}_{2} \mathrm{O}_{3} \cdot 6 \mathrm{H}_{2} \mathrm{O}$ & 378.30 & 150.00 & $-5,548.00$ & 2.52 \\
\hline Iron Hydroxide & $\mathrm{FH}_{3}$ & $\mathrm{Fe}_{2} \mathrm{O}_{3} \cdot 3 \mathrm{H}_{2} \mathrm{O}$ & 213.73 & 69.80 & -823.90 & 3.00 \\
\hline Water & $\mathrm{H}$ & $\mathrm{H}_{2} \mathrm{O}$ & 18.02 & 18.00 & -285.83 & 1.00 \\
\hline
\end{tabular}


Pure SWFA and pure cement samples had been analyzed for chemical composition using XRF.

\section{Chemical Processes}

The main phases at the start of the reaction were created using the Bogue calculation. An adjustment was made on these equations to cater for gypsum by deducting $0.7 \mathrm{xSO}_{3}$ from the total $\mathrm{CaO}$ [2]. $\mathrm{SO}_{3}$ is considered in the Bogue calculation because it is a component of gypsum $\left(\mathrm{CaO} . \mathrm{SO}_{3} .2 \mathrm{H}_{2} \mathrm{O}\right)$, one of the main cement phases. Other oxides e.g. $\mathrm{TiO}_{2}, \mathrm{Na}_{2} \mathrm{O}$ and $\mathrm{K}_{2} \mathrm{O}$ are not components of the main cement phases thus are not considered in the Bogue calculation.

The oxides used as model inputs were derived from chemical analyses of the cement and the ash separately. Oxides percentages for the SWFA-Cement mixes (ie 4, 8, 12, $16 \& 20 \%$ ) were calculated from the laboratory determined oxides percentages of the pure SWFA and pure cement. Table 2 gives these percentages.

Table 2 Percentage of oxides in various samples used as inputs to the model

\begin{tabular}{|c|c|c|c|c|c|c|c|c|c|c|c|c|}
\hline $\begin{array}{c}\text { \% Cement } \\
\text { Replacement }\end{array}$ & $\mathbf{S i O}_{2}$ & $\mathbf{A l}_{2} \mathbf{O}_{3}$ & $\mathbf{C a O}$ & $\mathbf{M g O}$ & $\mathbf{N a}_{2} \mathbf{O}$ & $\mathbf{K}_{2} \mathbf{O}$ & $\mathbf{T i O}_{2}$ & $\mathbf{M n O}$ & $\mathbf{F e}_{2} \mathbf{O}_{3}$ & $\mathbf{S O}_{3}$ & LOI & TOTAL \\
\hline $\mathbf{0 \%}$ & 17.96 & 4.07 & 60.87 & 4.00 & 0.23 & 0.48 & 0.08 & 0.05 & 2.93 & 2.60 & 5.82 & 99.09 \\
\hline $\mathbf{4 \%}$ & 19.92 & 4.26 & 58.55 & 3.87 & 0.24 & 0.55 & 0.11 & 0.08 & 3.01 & 2.51 & 5.96 & 99.06 \\
\hline $\mathbf{8 \%}$ & 21.88 & 4.45 & 56.24 & 3.74 & 0.25 & 0.62 & 0.14 & 0.11 & 3.08 & 2.42 & 6.10 & 99.03 \\
\hline $\mathbf{1 2 \%}$ & 23.84 & 4.64 & 53.92 & 3.61 & 0.25 & 0.69 & 0.17 & 0.13 & 3.16 & 2.34 & 6.24 & 99.01 \\
\hline $\mathbf{1 6 \%}$ & 25.81 & 4.83 & 51.61 & 3.48 & 0.26 & 0.76 & 0.20 & 0.16 & 3.24 & 2.25 & 6.38 & 98.98 \\
\hline $\mathbf{2 0 \%}$ & 27.77 & 5.02 & 49.29 & 3.35 & 0.27 & 0.83 & 0.23 & 0.19 & 3.31 & 2.16 & 6.52 & 98.95 \\
\hline $\mathbf{1 0 0 \%}$ & 67.00 & 8.82 & 2.98 & 0.75 & 0.42 & 2.25 & 0.83 & 0.75 & 4.85 & 0.40 & 9.34 & 98.39 \\
\hline
\end{tabular}

The modeling of the chemical reactions involved in the hydration process was then carried out. Results of the chemical analyses initially carried out formed the inputs into this process. The model sought to predict the hydration reactions in the first 24 hours after the preparation of the cement mix pastes.

Four main phases in cement were considered at the start of the analysis. This was in line with Bogue's calculation. These are $\mathrm{C}_{3} \mathrm{~S}$, $\mathrm{C}_{2} \mathrm{~S}, \mathrm{C}_{3} \mathrm{~A}$, and $\mathrm{C}_{4} \mathrm{AF}$. From the chemical notations, the most critical element is Calcium Oxide (Lime). The quantity of this was assumed to control the amount of hydration that will occur since the w/c ratio of 0.53 more than adequately provided for the water required for the hydration process.

Due to the fairly high w/c ratio used in this study (0.53), it was assumed that there is sufficient water, since full hydration of cement requires a w/c ratio of about 0.25 [3]. The limiting components were therefore the other elements (phases) other than water. This is a simplistic approach because some of the water supplied as w/c ratio is known to be used for wetting the aggregates, among other uses, and therefore the exact amount of water available for the hydration would be less than the 0.53 provided.

\section{Reaction Rules}

The following rules were adopted by model SWFAHYD in carrying out the reactions:

\section{Reactants shared by more than one reaction}

Reactants in this discussion refer to the phases that react and are consumed to produce other phases refered to as products. At the start of the hydration process, the main reactants are $\mathrm{C}_{3} \mathrm{~S}, \mathrm{C}_{2} \mathrm{~S}, \mathrm{C}_{3} \mathrm{~A}, \mathrm{C}_{4} \mathrm{AF}$ and $\mathrm{H}$, then later in the reactions; $\mathrm{CSH}_{2}$ and $\mathrm{C}_{6} \mathrm{AS}_{3} \mathrm{H}_{32}$.

Table 3 Relative quantities allocated to reactions sharing phases

\begin{tabular}{|l|l|}
\hline Reaction & $\begin{array}{l}\text { Percentage } \\
\text { Allocated }\end{array}$ \\
\hline $\mathrm{C}_{3}$ A Sharing Reactions & $89 \%$ \\
\hline $\mathrm{C}_{3} \mathrm{~A}+6 \mathrm{H} \rightarrow \mathrm{C}_{3} \mathrm{AH}_{6}$ & \\
\hline
\end{tabular}




\begin{tabular}{|c|c|}
\hline $\mathrm{C}_{3} \mathrm{~A}+3 \mathrm{CSH}_{2}+26 \mathrm{H} \rightarrow \mathrm{C}_{6} \mathrm{AS}_{3} \mathrm{H}_{32}$ & $10 \%$ \\
\hline $2 \mathrm{C}_{3} \mathrm{~A}+\mathrm{C}_{6} \mathrm{AS}_{3} \mathrm{H}_{32}+4 \mathrm{H} \rightarrow 3 \mathrm{C}_{4} \mathrm{ASH}_{12}$ & $1 \%$ \\
\hline \multicolumn{2}{|l|}{$\mathrm{C}_{4} \mathrm{AF}$ Sharing Reactions } \\
\hline $\mathrm{C}_{4} \mathrm{AF}+3 \mathrm{CSH}_{2}+30 \mathrm{H} \rightarrow \mathrm{C}_{6} \mathrm{AS}_{3} \mathrm{H}_{32}+\mathrm{CH}+\mathrm{FH}_{3}$ & $5 \%$ \\
\hline $2 \mathrm{C}_{4} \mathrm{AF}+\mathrm{C}_{6} \mathrm{AS}_{3} \mathrm{H}_{32}+12 \mathrm{H} \rightarrow 3 \mathrm{C}_{4} \mathrm{ASH}_{12}+2 \mathrm{CH}+2 \mathrm{FH}_{3}$ & $5 \%$ \\
\hline $\mathrm{C}_{4} \mathrm{AF}+10 \mathrm{H} \rightarrow \mathrm{C}_{3} \mathrm{AH}_{6}+\mathrm{CH}+\mathrm{FH}_{3}$ & $90 \%$ \\
\hline \multicolumn{2}{|l|}{$\mathrm{CSH}_{2}$ Sharing Reactions } \\
\hline $\mathrm{C}_{3} \mathrm{~A}+3 \mathrm{CSH}_{2}+26 \mathrm{H} \rightarrow \mathrm{C}_{6} \mathrm{AS}_{3} \mathrm{H}_{32}$ & $95 \%$ \\
\hline $\mathrm{C}_{4} \mathrm{AF}+3 \mathrm{CSH}_{2}+30 \mathrm{H} \rightarrow \mathrm{C}_{6} \mathrm{AS}_{3} \mathrm{H}_{32}+\mathrm{CH}+\mathrm{FH}_{3}$ & $5 \%$ \\
\hline \multicolumn{2}{|l|}{$\mathrm{C}_{6} \mathrm{AS}_{3} \mathrm{H}_{32}$ Sharing Reactions } \\
\hline $2 \mathrm{C}_{3} \mathrm{~A}+\mathrm{C}_{6} \mathrm{AS}_{3} \mathrm{H}_{32}+4 \mathrm{H} \rightarrow 3 \mathrm{C}_{4} \mathrm{ASH}_{12}$ & $90 \%$ \\
\hline $2 \mathrm{C}_{4} \mathrm{AF}+\mathrm{C}_{6} \mathrm{AS}_{3} \mathrm{H}_{32}+12 \mathrm{H} \rightarrow 3 \mathrm{C}_{4} \mathrm{ASH}_{12}+2 \mathrm{CH}+2 \mathrm{FH}_{3}$ & $10 \%$ \\
\hline
\end{tabular}

Reactions were carried out in reverse in the model such that the products took molar quantities of the respective limiting reactants. The user inputs the desired age of the paste at the stage of entering values for the initial oxides. The model then uses this to calculate the phase quantities at the chosen time, by limiting the amount of reaction that occurs. This, the model does by calculating and allowing only a fraction of the initial cementing phases to react. The value of the fraction is given by Equation 1 .

$$
\text { Available Fraction }=\frac{\text { Selected Age }(\text { Hours })}{24(\text { Hours })}
$$

This relationship assumes a linear behavior of hydration with time. This assumption was found not to agree with the laboratory tests carried out on SWFA-Cement paste for chemical shrinkage, which showed a higher reaction rate at early ages which then slowed down.

To capture the acceleration of the hydration reaction at early hours of the reaction, laboratory shrinkage results were averaged and plotted (Figure 2). From the graph a formula was derived (Equation 2) and adjusted to give an output of unity (1.0) at a value input of $\mathrm{x}=24$, where $\mathrm{x}$ is the age of the paste in hours (Equation 3). 


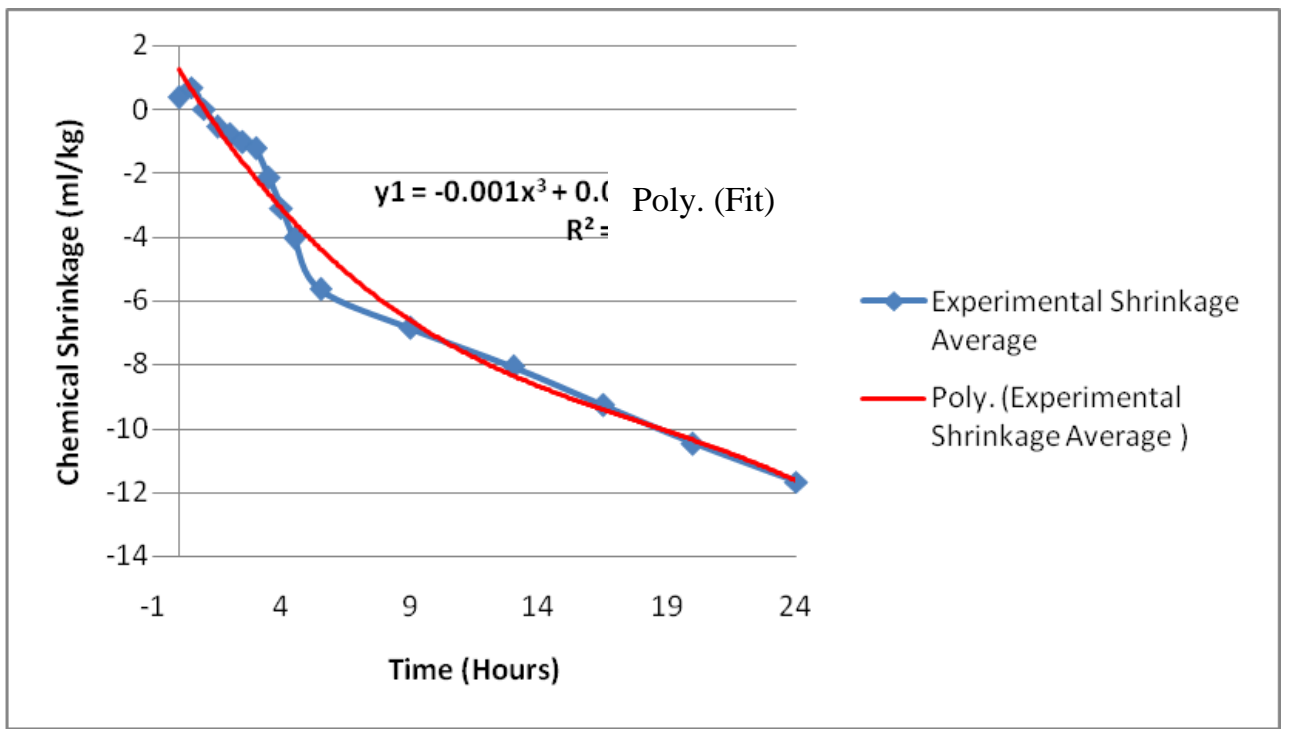

Figure 2 Curve fitting of values of chemical shrinkage obtained from experimental results

$$
\begin{aligned}
& y_{1}=-0.001 x^{3}+0.057 x^{2}-1.306 x+1.259 \\
& y_{2}=-0.0000902 x^{3}+0.00514 x^{2}-0.1178 x+0.113
\end{aligned}
$$

Where $\quad y_{1}=$ Average shrinkage directly from curve fitted on the experimental results

$$
\begin{aligned}
& \mathrm{y}_{2}=\text { Average shrinkage after adjustment such that } \mathrm{y}_{2}=1.0 \text { when } \mathrm{x}=24 \\
& \mathrm{x}=\text { Paste Age (Hours) }
\end{aligned}
$$

Total heat of hydration and chemical shrinkage at the chosen time are then calculated based on the phase quantities consumed and formed.

\section{Silicate Reactions}

NB: Values indicated below the reaction equations are volume stoichiometries

Reaction 1: Formation of calcium silicate hydrate from the hydration of tricalcium silicate [1]:

$\mathrm{C}_{3} \mathrm{~S}+5.3 \mathrm{H} \rightarrow \mathrm{C}_{1.7} \mathrm{SH}_{4}+1.3 \mathrm{CH}$

$1 \quad 1.34 \quad 1.521 \quad 0.61$

For every mole of tricalcium silicate $\left(\mathrm{C}_{3} \mathrm{~S}\right)$ reacted, the model created 1 mole of calcium silicate hydrate $\left(\mathrm{C}_{1.7} \mathrm{SH}_{4}\right), 1.3$ moles of calcium hydroxide $(\mathrm{CH})$. The reaction used 5.3 moles of water

Reaction 2: Formation of calcium silicate hydrate from the hydration of dicalcium silicate:

$\mathrm{C}_{2} \mathrm{~S}+4.3 \mathrm{H} \rightarrow \mathrm{C}_{1.7} \mathrm{SH}_{4}+0.3 \mathrm{CH}$

$1 \quad 1.49 \quad 2.077 \quad 0.191$

For every mole of dicalcium silicate $\left(\mathrm{C}_{2} \mathrm{~S}\right)$ reacted, the model created 1 mole of calcium silicate hydrate $\left(\mathrm{C}_{1.7} \mathrm{SH}_{4}\right), 0.3$ moles of calcium hydroxide $(\mathrm{CH})$, and 4.3 moles of water were used.

\section{Aluminate and Ferrite Reactions}

Reaction 3: Formation of hydrogarnet from hydration of tricalcium aluminate [1]:

$\mathrm{C}_{3} \mathrm{~A}+6 \mathrm{H} \rightarrow \mathrm{C}_{3} \mathrm{AH}_{6}$

$1 \quad 1.21 \quad 1.69$

The model creates the same number of hydrogarnet $\left(\mathrm{C}_{3} \mathrm{AH}_{6}\right)$ moles, as the number of moles of tricalcium aluminate available for this reaction. For every mole of hydrogarnet formed, the model uses 6 moles of water.

\section{Reaction 4: Formation of ettringite from hydration of tricalcium aluminate \& gypsum:}




$$
\begin{aligned}
& C_{3} A+3 C \bar{S} H_{2}+26 H \rightarrow C_{6} A \overline{S_{3}} H_{32} \\
& \begin{array}{llll}
0.4 & 1 & 2.1 & 3.3
\end{array}
\end{aligned}
$$

For the formation of ettringite $\left(\mathrm{C}_{6} \mathrm{AS}_{3} \mathrm{H}_{32}\right)$, the model checks for the limiting reactant i.e. the smaller of either; $\mathrm{C}_{3} \mathrm{~A}$ moles available for this reaction, or 1/3 times the moles of gypsum $\left(\mathrm{CSH}_{2}\right)$ available for this reaction.

The model then creates ettringite quantities based on this limiting reactant ie moles of ettringite formed in this reaction to be equal to either moles of $\mathrm{C}_{3} \mathrm{~A}$ or 0.33 times number of moles of gypsum reacted. Then for every mole of ettringite formed, the model uses 26 moles of water.

\section{Reaction 5: Formation of monosulfate from the hydration of tricalcium aluminate, and ettringite:}

$$
\begin{array}{lccc}
2 C_{3} A+C_{6} A \overline{S_{3}} H_{32}+4 H \rightarrow & 3 C_{4} A \bar{S} H_{12} \\
0.2424 & 1 & 0.098 & 1.278
\end{array}
$$

For the formation of monosulfate $\left(\mathrm{C}_{4} \mathrm{ASH}_{12}\right)$, the model checks for the limiting reactant i.e. the smaller of either; $\mathrm{C}_{3} \mathrm{~A}$ moles available for this reaction, or $1 / 2$ times the moles of ettringite $\left(\mathrm{C}_{6} \mathrm{AS}_{3} \mathrm{H}_{32}\right)$ available for this reaction.

The model then creates monosulfate quantities based on this limiting reactant ie moles of monosulfate formed in this reaction to be equal to either 3 times the moles of ettringite reacted or 1.5 times the moles of tricalcium aluminate. For every mole of monosulfate formed, the model uses 1.33 moles of water

\section{Reaction 6: Formation of ettringite, calcium hydroxide, and iron hydroxide, from the hydration of tetracalcium alumino ferrite and gypsum:}

$$
\begin{aligned}
& \mathrm{C}_{4} \mathrm{AF}+3 \mathrm{C} \overline{\mathrm{S}} \mathrm{H}_{2}+30 \mathrm{H} \rightarrow \mathrm{C}_{6} A \bar{S}_{3} \mathrm{H}_{32}+\mathrm{CH}+\mathrm{FH}_{3} \\
& \begin{array}{llllll}
0.575 & 1 & 2.426 & 3.3 & 0.15 & 0.31
\end{array}
\end{aligned}
$$

For the formation of ettringite $\left(\mathrm{C}_{6} \mathrm{AS}_{3} \mathrm{H}_{32}\right)$, calcium hydroxide $(\mathrm{CH})$, and iron hydroxide $\left(\mathrm{FH}_{3}\right)$ the model checks for the limiting reactant i.e. the smaller of either; $\mathrm{C}_{4} \mathrm{AF}$ moles available for this reaction, or $1 / 3$ times the moles of gypsum $\left(\mathrm{CSH}_{2}\right)$ available for this reaction.

The model then creates ettringite, $\mathrm{CH}$ and $\mathrm{FH}_{3}$ based on the limiting reactant ie moles of ettringite, $\mathrm{CH}$ and $\mathrm{FH}_{3}$ formed to be equal to $\mathrm{C}_{4} \mathrm{AF}$ moles reacted or $1 / 3$ of gypsum moles reacted. The model then uses 30 moles of water for every mole of ettringite formed.

\section{Reaction 7: Formation of monosulfate from the hydration of tetracalcium alumino ferrite and ettringite:}

$$
\begin{aligned}
& 2 C_{4} A F+C_{6} \bar{S}_{3} H_{32}+12 \mathrm{H} \rightarrow 3 C_{4} A \bar{S} H_{12}+2 \mathrm{CH}+2 \mathrm{FH}_{3} \\
& \begin{array}{llllll}
0.348 & 1 & 0.294 & 1.278 & 0.09 & 0.19
\end{array}
\end{aligned}
$$

For the formation of monosulfate $\left(\mathrm{C}_{4} \mathrm{ASH}_{12}\right)$, calcium hydroxide $(\mathrm{CH})$, and iron hydroxide $\left(\mathrm{FH}_{3}\right)$ via the hydration of tetracalcium alumino ferrite and ettrigite, the model checks for the limiting reactant i.e. the smaller of either; $1 / 2$ times $\mathrm{C}_{4} \mathrm{AF}$ moles available for this reaction, or the moles of ettringite $\left(\mathrm{C}_{6} \mathrm{AS}_{3} \mathrm{H}_{32}\right)$ available for this reaction.

The model then creates monosulfate, $\mathrm{CH}$ and $\mathrm{FH}_{3}$ based on the limiting reactant ie for every mole of $\mathrm{C}_{4} \mathrm{AF}$ reacted, 1.5 moles of monosulfate, 1 mole of $\mathrm{CH}$ and 1 mole of $\mathrm{FH}_{3}$ are formed, and for every mole of ettringite reacted, 3 moles of monosulfate, 2 moles of $\mathrm{CH}$ and 2 moles of $\mathrm{FH}_{3}$. The model then uses 4 moles of water for every mole of ettringite formed.

\section{Reaction 8: Formation of hydrogarnet from the hydration of tetracalcium alumno ferrite:}

$$
\mathrm{C}_{4} \mathrm{AF}+10 \mathrm{H} \rightarrow \mathrm{C}_{3} \mathrm{AH}_{6}+\mathrm{CH}+\mathrm{FH}_{3}
$$
1
$1.41 \quad 1.17$
0.26
0.545

For every mole of tetracalcium alumino ferrite reacted, the model creates one mole of hydrogarnet, calcium hydroxide and iron hydroxide, and uses 10 moles of water.

Reaction 9: Formation of calcium silicate hydrate from the reaction of calcium hydroxide and silica: 
Three moles of calcium hydroxide react with two moles of silica to form one mole of calcium silicate hydrate.

\section{Chemical Shrinkage}

The model uses molar volume values to calculate the chemical shrinkage. Initially total volume of the reactants is calculated as the volume of the formed main phases plus that of the oxides remaining after formation of the main phases. The molar volumes of the remaining oxides (after formation of the main phases) is calculated from the molar masses and densities of the oxides and are as given in Table 4 [1].

Table 4 Molar volumes of main oxides

\begin{tabular}{|l|l|l|r|r|r|}
\hline $\mathbf{C C N}$ & $\begin{array}{l}\text { Actual } \\
\text { Formula }\end{array}$ & Name & \multicolumn{1}{|l|}{$\begin{array}{l}\text { Molar } \\
\text { Mass }(\mathbf{g})\end{array}$} & $\begin{array}{l}\text { Density } \\
(\mathbf{g} / \mathbf{c m 3})\end{array}$ & \multicolumn{1}{l}{$\begin{array}{l}\text { Molar } \\
\text { Vol }\end{array}$} \\
\hline $\mathrm{C}$ & $\mathrm{CaO}$ & Calcium oxide or lime & 56.08 & 3.35 & 16.74 \\
\hline $\mathrm{S}$ & $\mathrm{SiO}_{2}$ & Silicon dioxide or silica & 60.09 & 2.648 & 22.69 \\
\hline $\mathrm{A}$ & $\mathrm{Al}_{2} \mathrm{O}_{3}$ & Aluminium oxide or alumina & 101.96 & 4.025 & 25.33 \\
\hline $\mathrm{F}$ & $\mathrm{Fe}_{2} \mathrm{O}_{3}$ & Iron oxide & 159.68 & 5.242 & 30.46 \\
\hline
\end{tabular}

The total volume of the created phases and remaining (unreacted) oxides is calculated at the start and end of the hydration reaction calculations. This is then used to calculate the chemical shrinkage as the change in total volume per unit mass of the cement, given by Equation 4:

$$
\text { Shrinkage }=\frac{V_{0}-V_{\text {final }}}{100} \quad \text { (per gram) }
$$

Where $\mathrm{V}_{\mathrm{o}} \quad=$ total initial volume

$\mathrm{V}_{\text {final }} \quad=$ total final volume

The denominator value in the shrinkage equation is used since the model assumes $100 \mathrm{~g}$ of cement. The shrinkage is calculated in $\mathrm{cm}^{3} / \mathrm{g}$ of cement.

\section{Heat of Hydration}

The model calculates the heat of hydration by using Equation 5 [4].

$H_{\text {CEm }}=500 p_{C_{2} S}+260 p_{C_{2} S}+866 p_{C_{2} A}+420 p_{C_{4} A F}+64 p_{S_{3}}+1186 p_{\text {FreECOO }}+850 p_{M g O}$

Where:

$\mathrm{H}_{\mathrm{cem}} \quad=$ total heat of hydration of the cement (Joule/g),

$\mathrm{p}_{\mathrm{i}} \quad=$ weight ratio of $\mathrm{i}$-th compound in terms of the total cement content

Only the first four terms of the Equation 5, free $\mathrm{CaO}$ (assumed as $1 \%$ of the total cementing material weight [2]) and $\mathrm{MgO}$ are considered in the model. The used quantities of the initial four phases are calculated, the weights derived from the number of moles (since the reactions were in number of moles), their percentage of the initial weight calculated and put into Equation (5) to give the heat of hydration released.

\section{Water}

The model also calculates the water quantities used in each hydration reaction based on the amount of the limiting reactant used. The model then sums up the water quantities used in all the reactions and outputs this in moles.

\section{Concrete Strength Predictions}


The model uses the calculated chemical shrinkage and an assumed value of bulk modulus of concrete of 9.6 GPa (24 hour bulk modulus of concrete class 25) to calculate the strength of the concrete mixes using equation 4.8 derived from energy principles [5].

$\Delta W_{B}=-\frac{K}{2} \cdot(\Delta \theta)^{2} \cdot V_{o}=\sigma_{t} \cdot V_{o}$

OR

$\sigma_{t}=\frac{-K}{2}(\Delta \theta)^{2}$

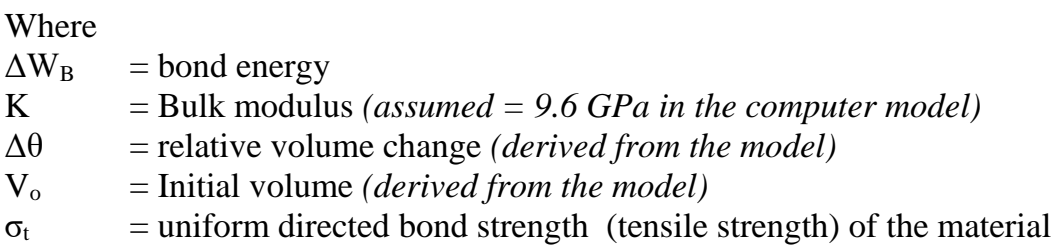

The bulk modulus value of $9.6 \mathrm{GPa}$, and degree of hydration in the first 24 hours assumed to be $30 \%$ of total possible hydration [6] are fixed in the model so as to restrict the variables only to time variation within the first 24 hours and oxide percentages. The model outputs for tensile strength at 24 hours were compared to laboratory tensile splitting results for 24 hour old cylinder samples.

\section{Model User Interface}

The model provides the user with an input window for entering the values of the main oxides and the age of the paste in hours. The model then runs the analyses and gives outputs at the user's prompting. The model also allows the user to go back to the input window, change a parameter, say the age of the paste, and reanalyze for revised outputs.

\section{Model Summary}

The model processes are summarized in the flow chart shown in Figure 3. 


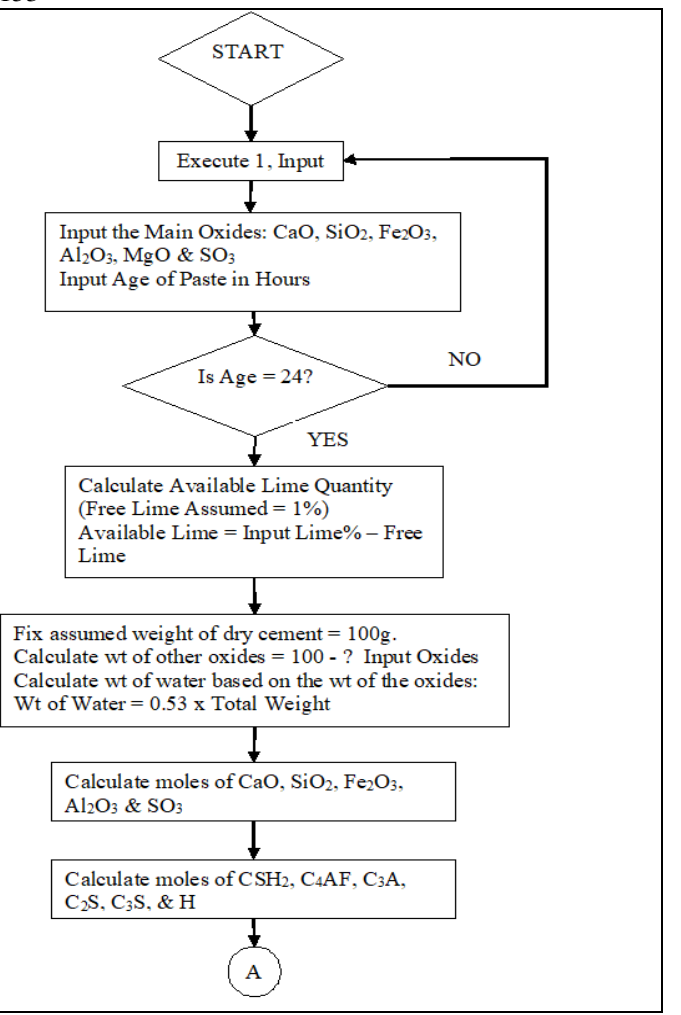

Figure 3 Computer model flow chart for the hydration of cement-SWFA paste

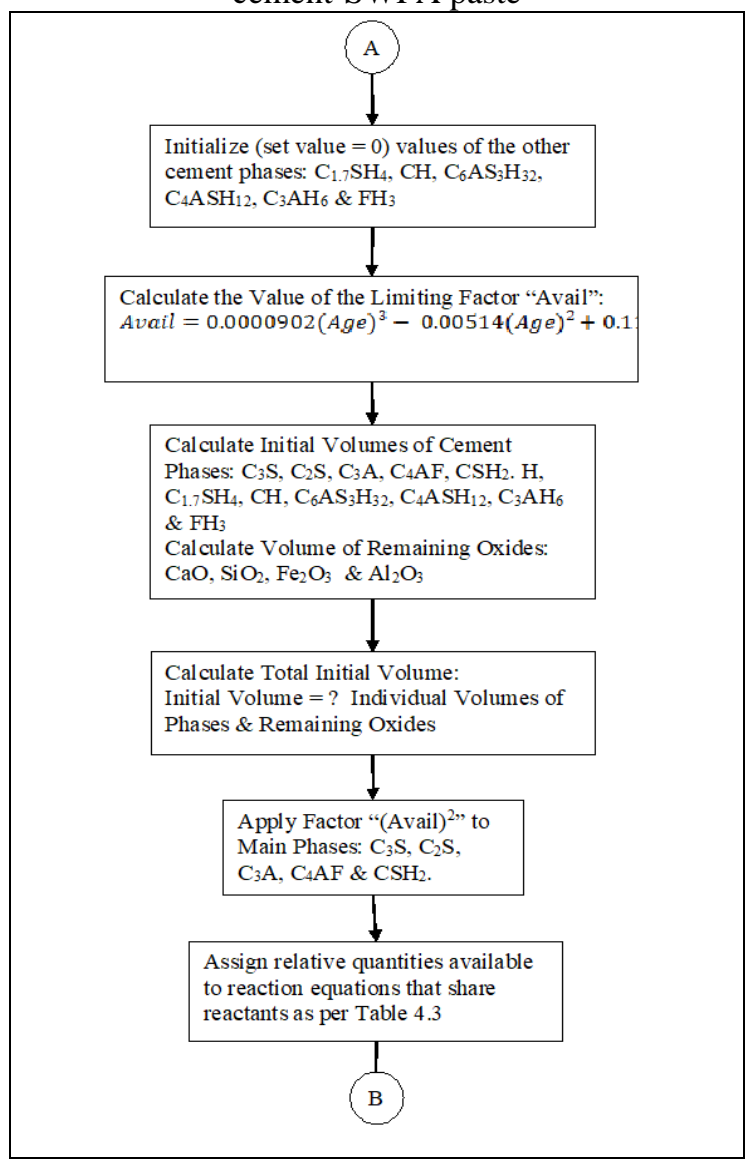



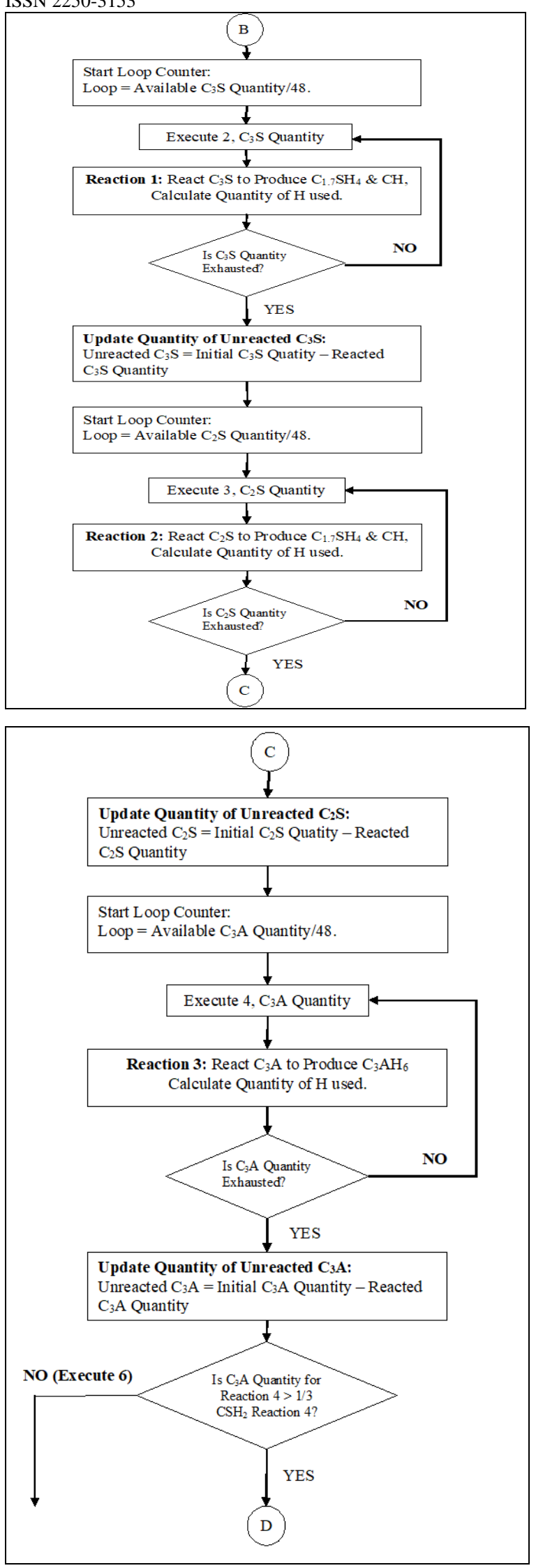

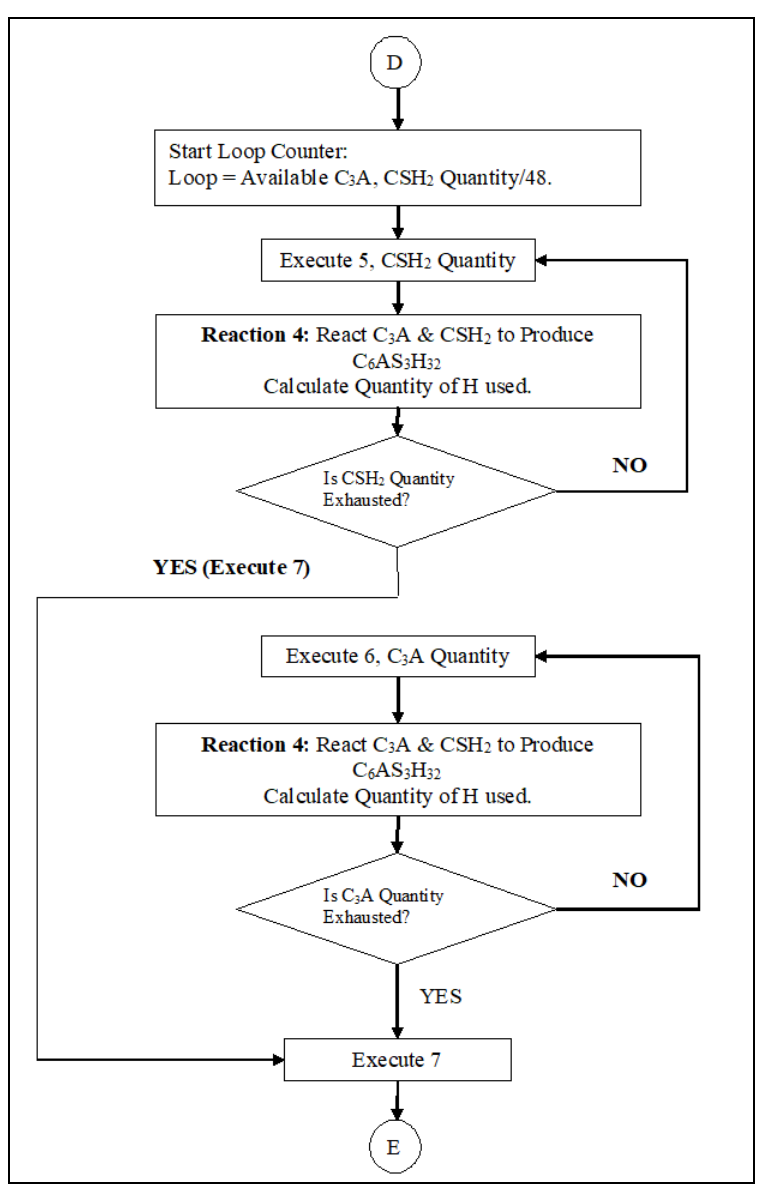



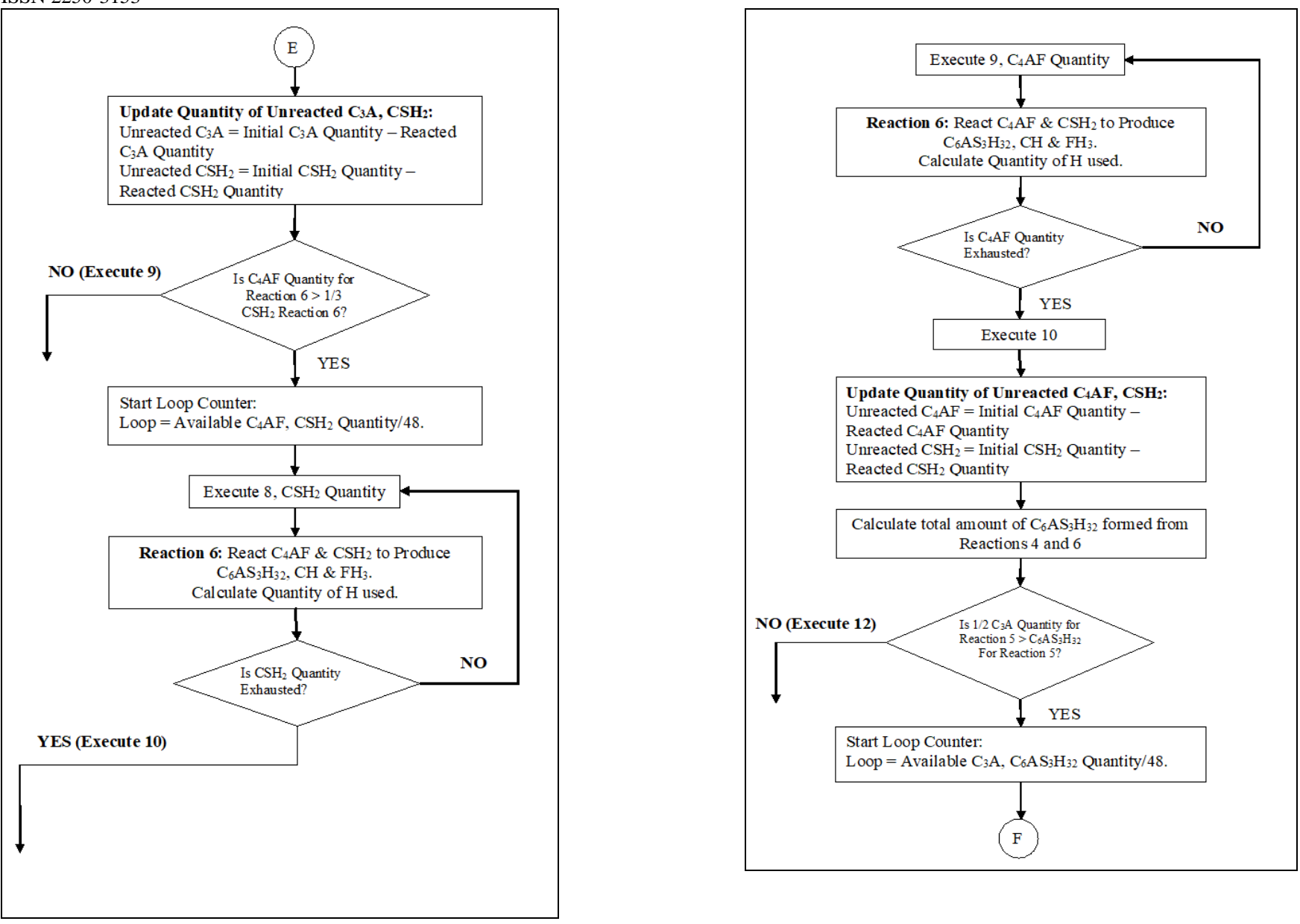

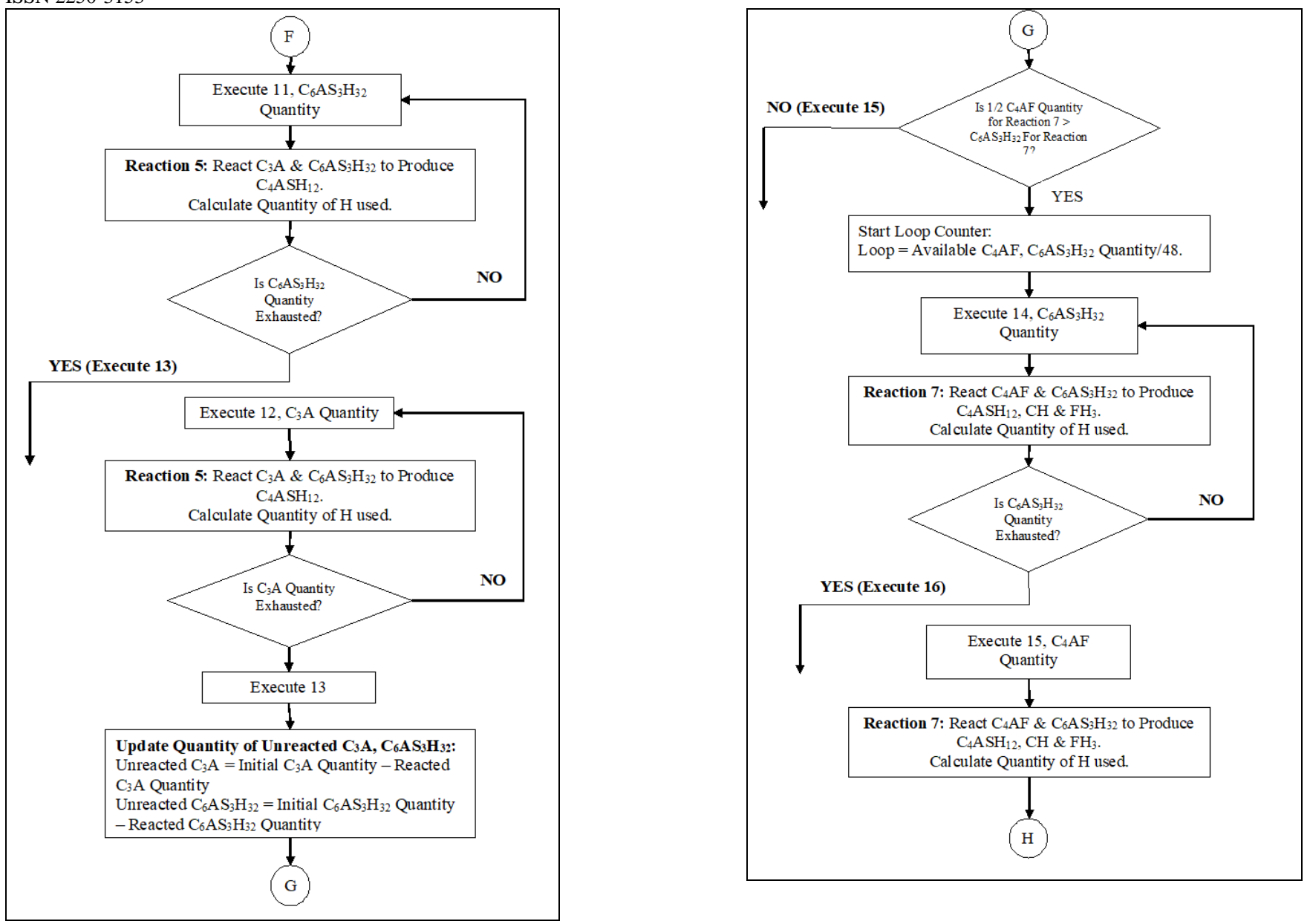

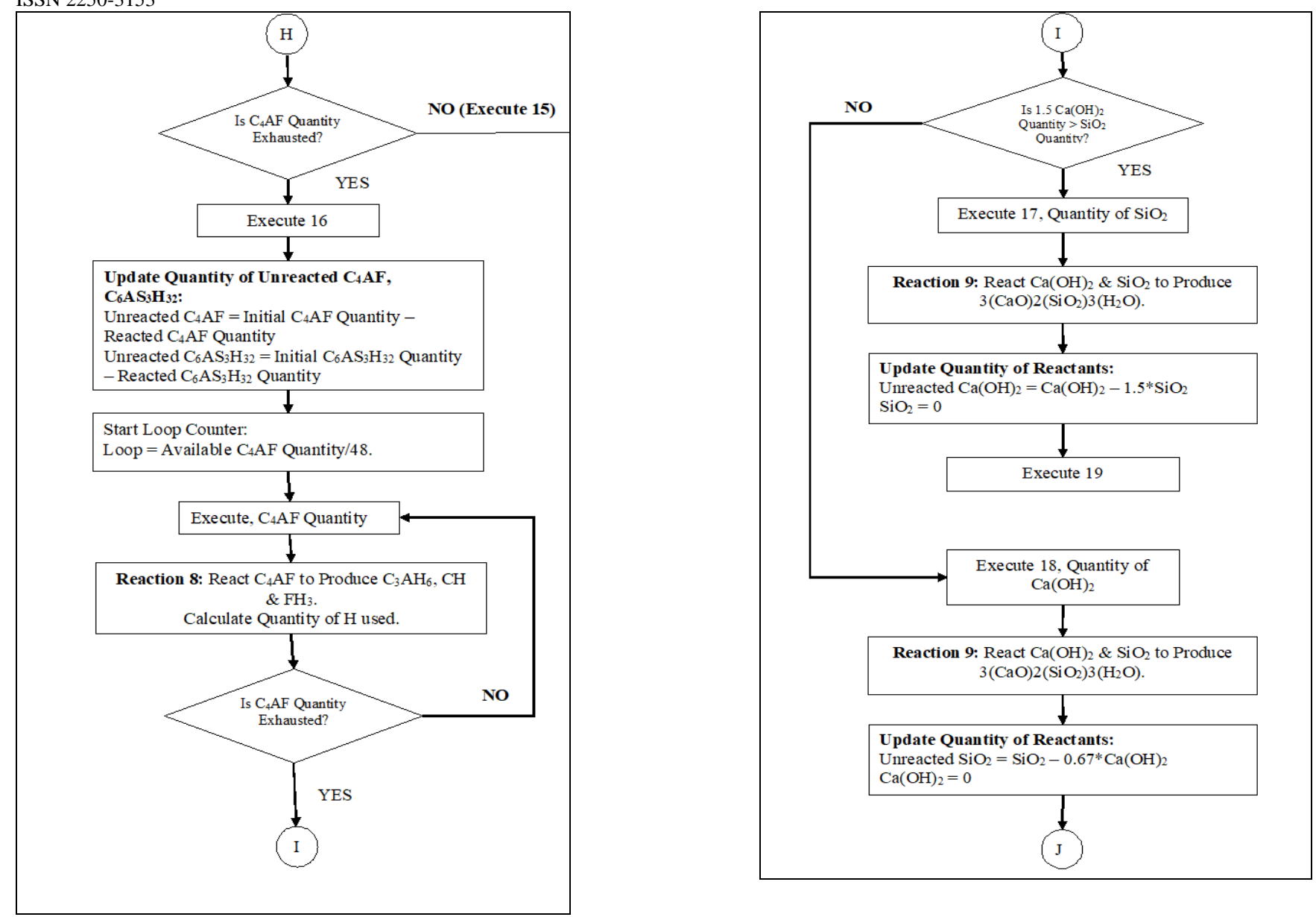


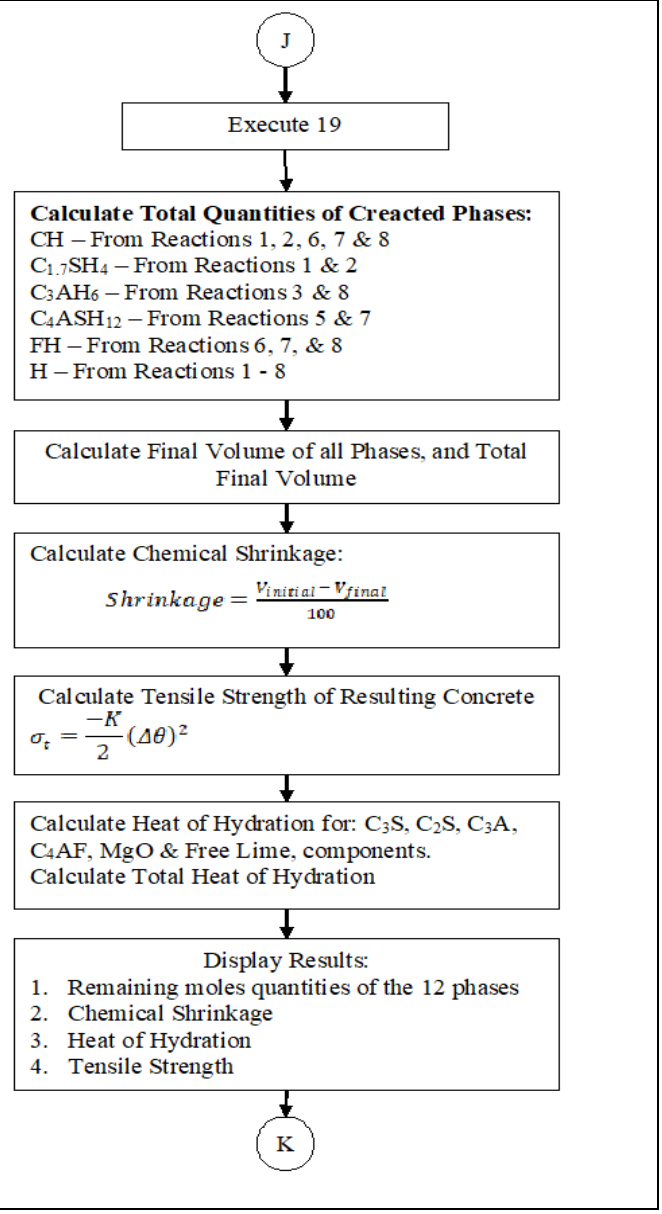




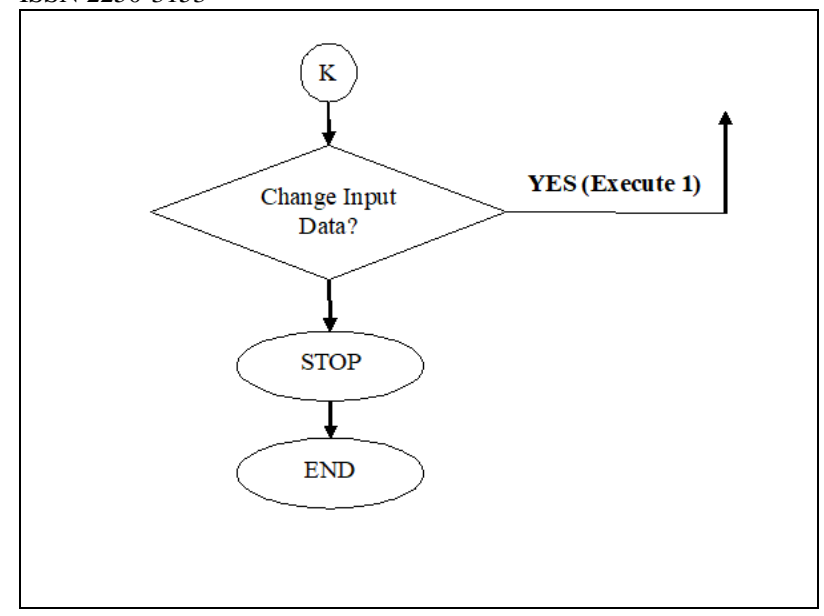

\section{RESULTS AND DISCUSSION}

\section{Model Results}

\section{Introduction}

The hydration model described in in the preceding sections was used to derive predictions for chemical shrinkage and heat of hydration for SWFA-cement pastes containing between $0-20 \%$ SWFA, and 28 day cube strength values for concrete mixes containing SWFA-cement of between $0-20 \%$ SWFA.

The results of these predictions were then compared to experimental measurements and the findings are discussed in the following sections.

\section{Chemical Shrinkage}

Chemical shrinkage values derived from the model were plotted against those measured from the lab and are given in the Figures 4 10. From these figures, the model results are approximately $50 \%$ higher than those determined experimentally in the laboratory. This difference might have been due to some of the assumptions taken within the model in the chemical shrinkage approximations. 25 percent hydration is assumed to occur in the first 24 hours after mixing of the SWFA-cement with water. It is possible that this degree of hydration was not achieved in the experimental pastes, resulting in a smaller volume reduction compared to the model shrinkage.

Also, in calculating the 25 percent degree of hydration, the model assumes that 25 percent of all the initial cement phases in the SWFA-cement paste $\left(\mathrm{C}_{3} \mathrm{~S}, \mathrm{C}_{2} \mathrm{~S}, \mathrm{C}_{3} \mathrm{~A}\right.$ and $\left.\mathrm{C}_{4} \mathrm{AF}\right)$ are hydrated. In real hydrating cement pastes, $\mathrm{C}_{3} \mathrm{~A}$ and $\mathrm{C}_{4} \mathrm{AF}$ hydration is much slower, going into months. This might also have contributed to the higher shrinkage predicted by the model.

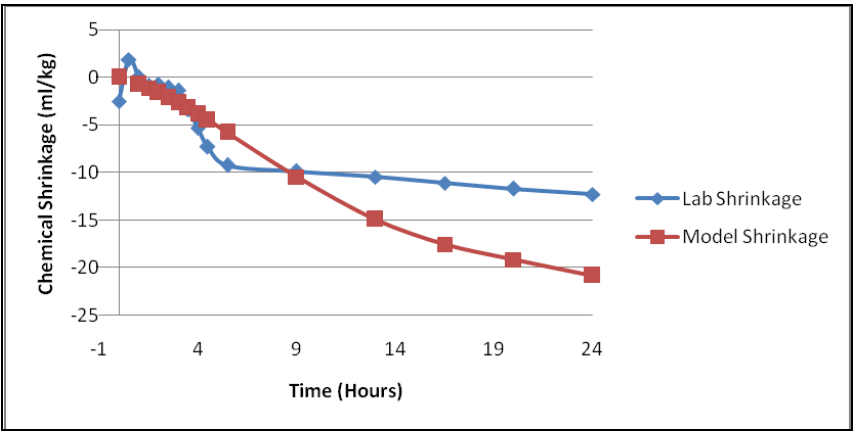

Figure 4 A comparison of numerical chemical shrinkage with experimental results: $0 \%$ SWFA

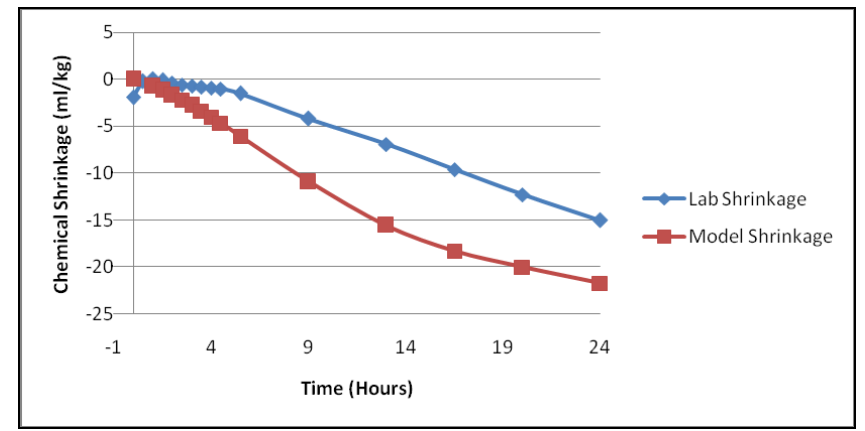

Figure 5 A comparison of numerical chemical shrinkage with experimental results: $4 \%$ SWFA 


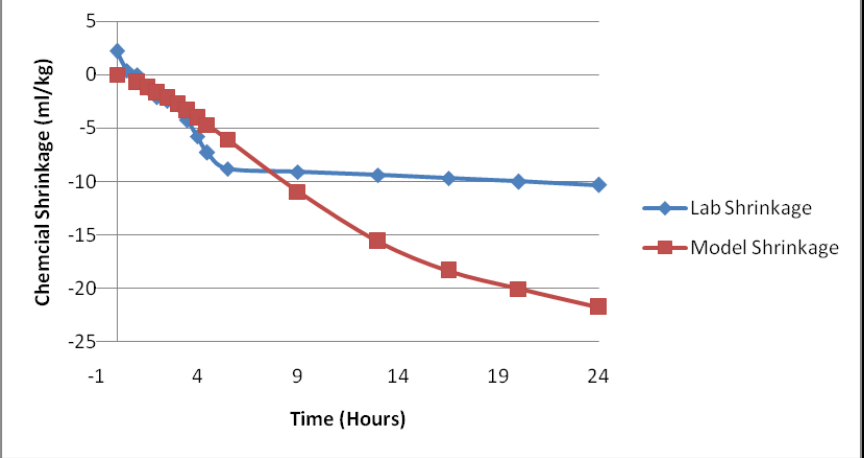

Figure 6 A comparison of numerical chemical shrinkage with experimental results: $8 \%$ SWFA

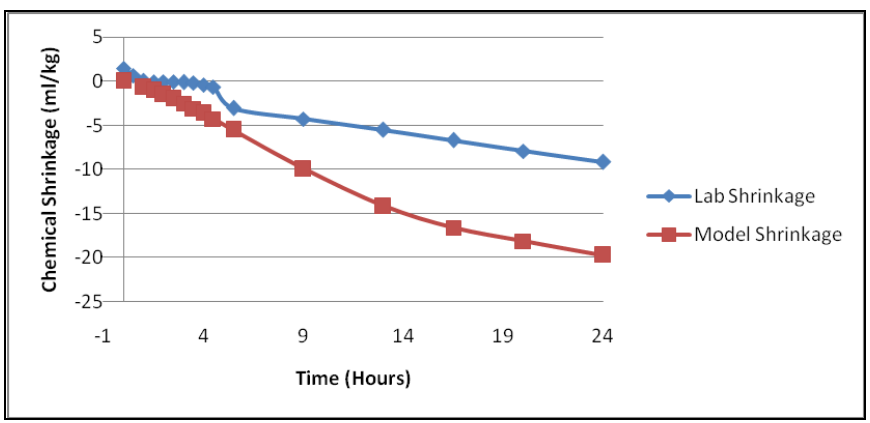

Figure 8 A comparison of numerical chemical shrinkage with experimental results: $16 \%$ SWFA

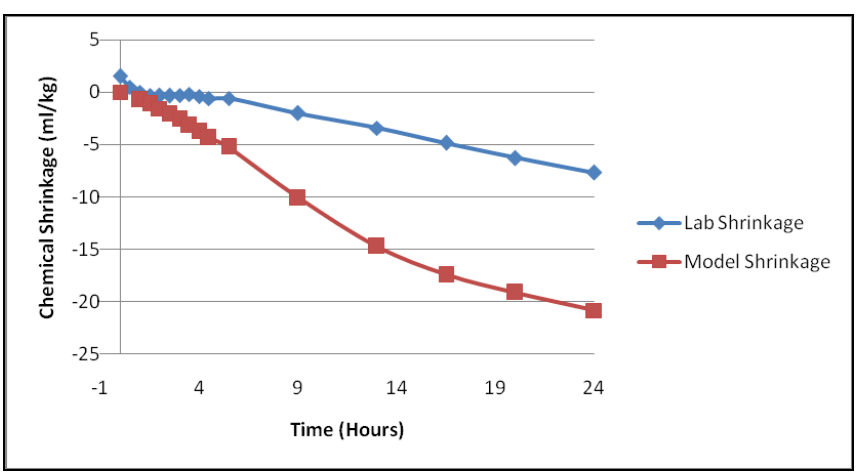

Figure 7 A comparison of numerical chemical shrinkage with experimental results: $12 \%$ SWFA

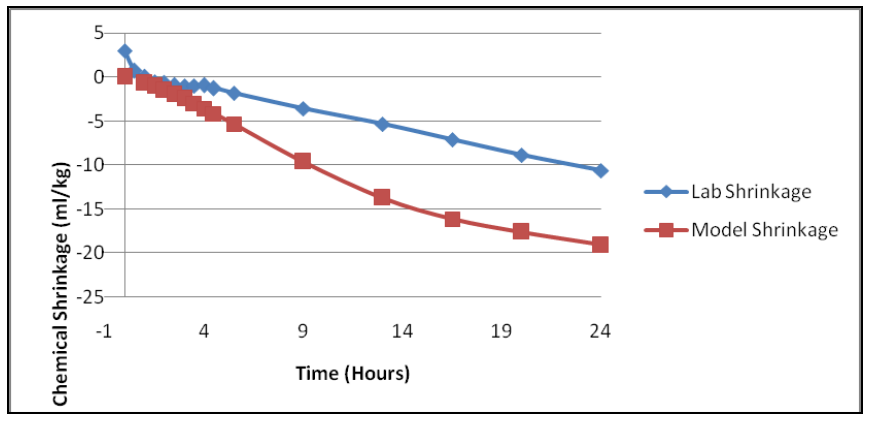

Figure 9 A comparison of numerical chemical shrinkage with experimental results: $20 \%$ SWFA

The 24 hour shrinkage values for the laboratory experiments and the model results are plotted in Figure 10. From this figure the model suggests an increase in the chemical shrinkage from $20.8 \mathrm{ml} / \mathrm{kg}$ at $0 \%$ SWFA content to an optimum value of $21.9 \mathrm{ml} / \mathrm{kg}$ at $6 \%$ SWFA content. The shrinkage then falls steadily to $19.1 \mathrm{ml} / \mathrm{kg}$ at $20 \%$ SWFA content. Laboratory results give a shrinkage of 12.3 $\mathrm{ml} / \mathrm{kg}$ for $0 \%$ SWFA content. The shrinkage then increases to a maximum value of $15 \% \mathrm{ml} / \mathrm{kg}$ at an optimum SWFA content of $4 \%$. This then reduces and increases again to a value of $10.6 \mathrm{ml} / \mathrm{kg}$ at $20 \%$ SWFA content. The difference between experimental and model values is thought to have been caused by the assumptions made in the model as discussed earlier in this section.

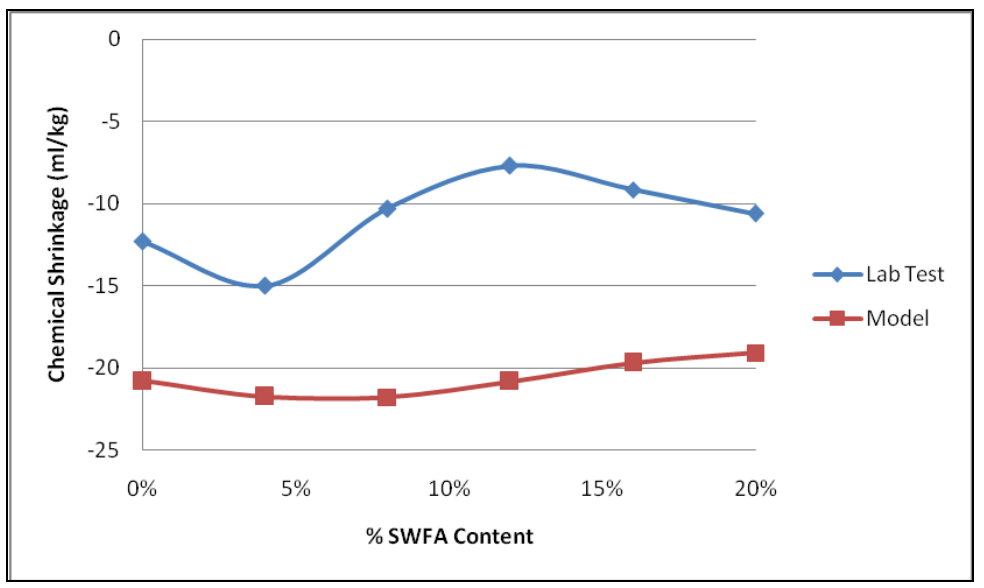

Figure 1024 hour chemical shrinkage - laboratory and model results

From these results (Figures $4-10$ ), the model suggests maximum shrinkage at about 6\% SWFA content. This is qualitatively in agreement with the $4 \%$ maximum shrinkage observed in the laboratory shrinkage values. 
The model is also seen to qualitatively predict the increase and later decrease in chemical shrinkage with increase in SWFA content. This suggests an increase followed by a decrease in amount of hydration reaction with increase in SWFA content, with an optimum occuring at about $6 \%$ SWFA content. This is in agreement with mechanical test results achieved on concrete containing these mixes. On average, the model 24-hour chemical shrinkage predictions are about $98 \%$ more than those observed in the laboratory (i.e. correlation factor of 1.98), as evidenced by Figures 4 to 10.

\subsubsection{Heat of Hydration}

The model calculates the heat of hydration values as described in the preceding sections of this paper. Figure 11 shows heat of hydration model predictions for the first 24 hours for the study SWFA-Cement mixes.

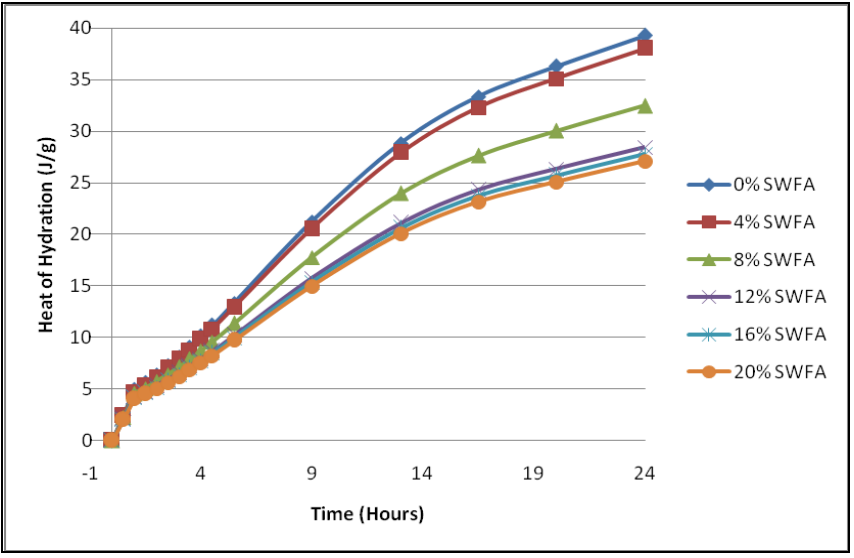

Figure 11 Numerically determined heat of hydration $(0-24$

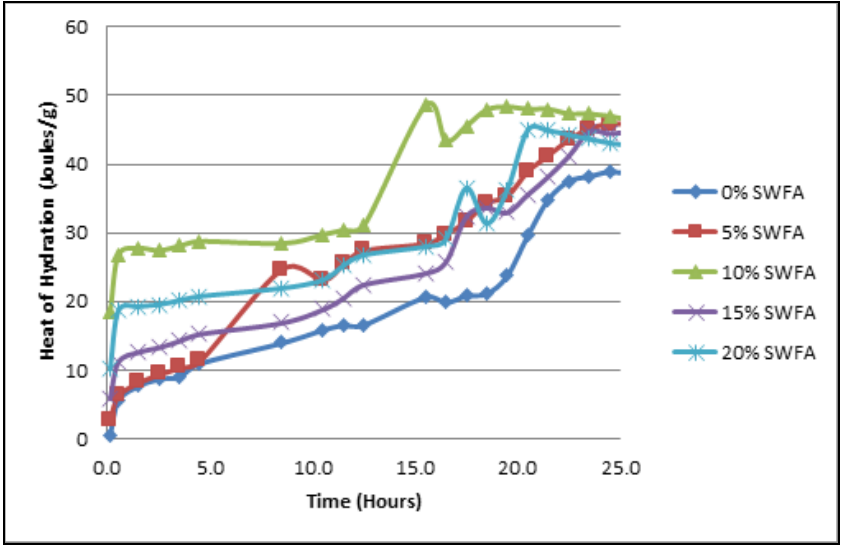

Figure 12 Average experimental heat of hydration for SWFA - cement mortars [7]

hours)

The model suggests a total heat of hydration value for cement without ash of about $39 \mathrm{~J} / \mathrm{g}$ at age 24 hours. The shape of the curves is in agreement with other laboratory test results (Figure 12 [7]). A steady drop of the amount of heat of hydration with ash content is also suggested in the model results (Figures $11 \& 13$ ). This is not fully in agreement with the laboratory results which show an increase in the heat of hydration with increase in SWFA content, up to about 6\% SWFA (Figure 13) followed by a steady decrease. On the average, the model predictions are about $73 \%$ of those gotten from the laboratory with the deviation between the model and laboratory results increasing with increase in SWFA content.

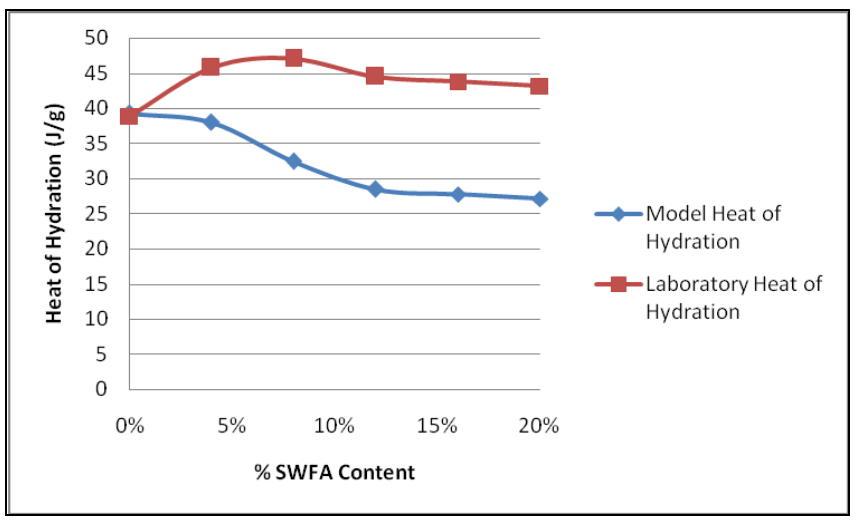

Figure 13 Comparison of numerical and experimental 24 hour heat of hydration

\section{Concrete Tensile and Compressive Strength}

Figure 14 gives model predictions for tensile strengths within the first 24 hours of hydration for concrete mixes containing SWFACement mixes. 


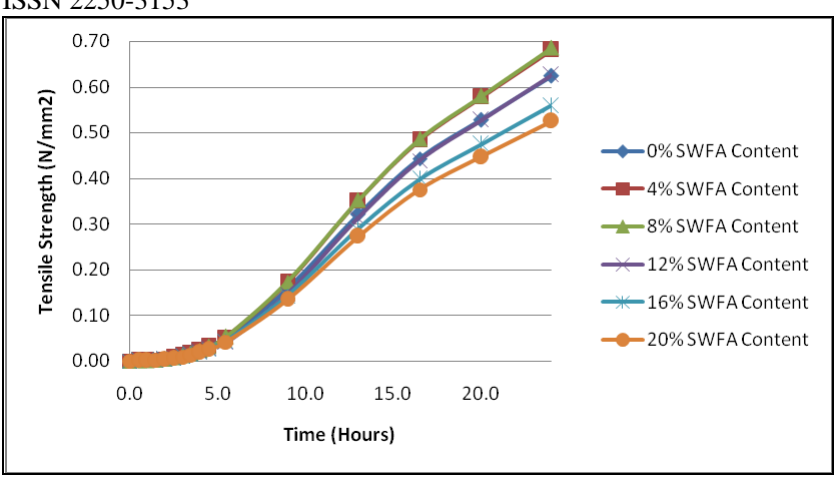

Figure 1424 hour model tensile strength results

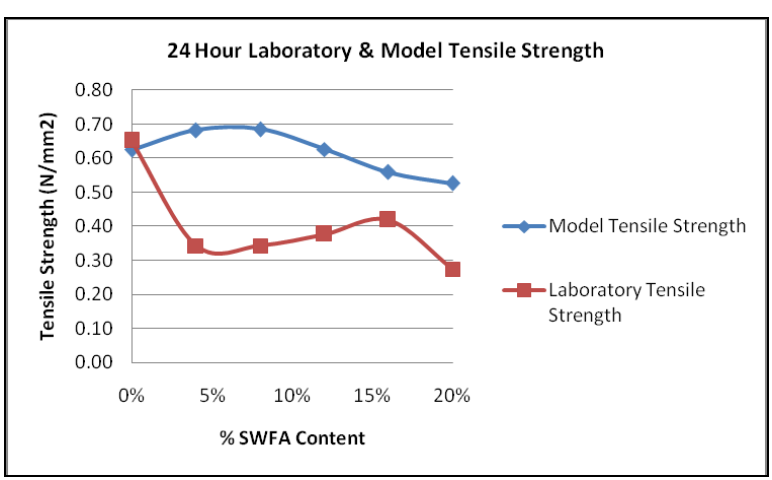

Figure 15 Comparison of 24 hour experimental and numerical tensile strength values

The model suggests 24 hour concrete tensile strength (Figure 14) values between $0.62 \mathrm{~N} / \mathrm{mm}^{2}$ and $0.53 \mathrm{~N} / \mathrm{mm}^{2}$ for $0 \%$ and $20 \%$ SWFA content respectively. Assuming that concrete cube strength is approximately 10x its tensile strength, this transforms to 6.2 $\mathrm{N} / \mathrm{mm}^{2}$ and $5.3 \mathrm{~N} / \mathrm{mm}^{2}$ compressive strength after the first 24 hours of curing.

The model also suggests a slower strength gain in the first 4 hours before an acceleration period of strength gain which starts to slow down again after 15 hours. This is in agreement with the behavior of concrete whereby hardening is delayed in the early hours before an acceleration in the rate of hydration and subsequently the strength gain.

Figure 15 shows 24 hour laboratory and model tensile strengths. The model suggests a tensile strength of $0.62 \mathrm{~N} / \mathrm{mm}^{2}$ for $0 \%$ SWFA content concrete. This compares well with the $0.65 \mathrm{~N} / \mathrm{mm}^{2}$ observed in the 24 hour tensile strength. The model then predicts an increase in the tensile strength to an optimum strength at about 6\% SWFA content. The laboratory results however show a decrease in tensile strength with a minimum occurring at approximately $6 \%$ SWFA content. The decrease has been attributed to possible cracking of the microstructure due to the higher amount of chemical shrinkage exhibited at 4\% SWFA content. Beyond 15\% SWFA both the model and laboratory predictions take a downward trend with increase in SWFA content. It is thought that this (15\% SWFA content) is the point at which excessive shrinkage stopped significantly affecting the tensile strength. With this consideration, the drop in tensile strength beyond 15\% SWFA content is almost entirely attributed to the reduction in hydration reactions. On the average, the model 24-hour tensile strength prediction is about 0.53 that achieved in the laboratory.

Assuming that about $25 \%$ of the concrete strength is achieved in the first 24 hours, and that the tensile strength of concrete is about $10 \%$ of its compressive strength [8], the 24 hour model outputs were used to approximate the 28 day strength of the concrete. The generated 28 day compressive strength values are plotted in Figure 16.

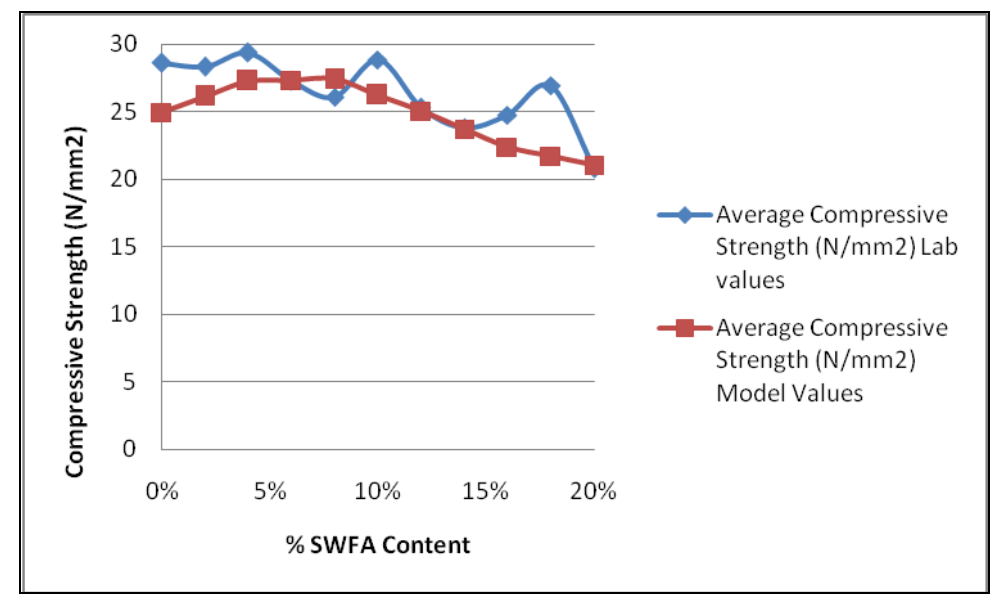

Figure 16 Average 28 day cube compressive strength (laboratory \& model results)

From Figure 16 the model compressive strength results approximately fit those of the laboratory. The model results show an increase from $25.0 \mathrm{~N} / \mathrm{mm}^{2}$ at $0 \%$ SWFA content to a maximum value of $27.3 \mathrm{~N} / \mathrm{mm}^{2}$ at $6 \%$ SWFA content, then a steady drop to $21.0 \mathrm{~N} / \mathrm{mm}^{2}$ at $20 \%$ SWFA content. Laboratory results gave a higher strength of $28.6 \mathrm{~N} / \mathrm{mm}^{2}$ at $0 \%$ SWFA content, with the rest of the results approximately agreeing with the model predictions. 
Using the assumptions: (i) the 24 hour tensile strength is about $25 \%$ of the 28 day strength, and (ii) the model is found to be able to predict closely the compressive strength of concrete containing $0-20 \%$ SWFA content. The model values are also conservative in that they are either in agreement or slightly lower than actual laboratory compressive strength values, with an average correlation of about 0.94 . The model strength predictions can therefore be safely used to predict the expected strengths of concretes containing between $0-20 \%$ SWFA.

The model is able to predict the chemical shrinkage of SWFA-Cement pastes closely for the early hours of hydration ( 0 - 4 hours $)$ and also at 24 hours. This is because the model relies on chemical reactions governed by the relative quantities of $\mathrm{CaO}, \mathrm{SiO}_{2}, \mathrm{Fe}_{2} \mathrm{O}_{3}$ and $\mathrm{Al}_{2} \mathrm{O}_{3}$ which were assumed to vary linearly with change in SWFA content in the cement paste.

\section{Conclusions}

The following conclusions can be made from this study:

1 The proposed hydration model is able to predict qualitatively the chemical shrinkage of SWFA-Cement pastes.

2 The proposed hydration model is able to qualitatively capture the increase in shrinkage between $4-6 \%$ SWFA content.

3 Within reasonable assumptions, the model is able to conservatively predict 28 day strength of concrete containing $0-20 \%$ SWFA content

\section{REFERENCES}

$1 \quad$ Bentz, D. P., (1995). A Three Dimensional Cement Hydration and Microstructure Program, Hydration Rate, Heat of Hydration, and Chemical Shrinkage. Building and Fire Research Laboratory, National Institute of Standards and Technology, Gaithersburg, Maryland 20899 \{http://ciks.cbt.nist.gov/bentz/nistir5756/\}

2 Understanding Cement, (2011) Portland Cement Clinker, The Bogue Calculation \{http://www.understandingcement.com/bogue.html\}.

3 Zhang Y.M., Napiermunn T.J. (1995). Effects of Particle-Size Distribution, Surface-Area and Chemical-Composition on Portland-Cement Strength. Powder $\quad$ Technology, $\quad$ Vol. $\quad 83(3), \quad$ Pp. \{http://www.cheric.org/research/techperiodicals/vol_view.php?\}

4 Schindler A. K., Folliard, K. J., (2005). Heat of Hydration Models for Cementitious Materials. ACI Materials Journal, Vol. 102(1), Pp. 24 - 33 \{http://www.allbusiness.com/manufacturing/nonmetallic-mineral-product-manufacturing/1041823-1.html\}

5 Paulini, P. (1992). A Weighing Method for Cement Hydration. $9^{\text {th }}$ International Congress on the Chemistry of Cement, New Delhi, Vol. IV, Pp. 248 - 254

6 Baron, A. R., (2010). Hydration of Portland Cement. \{http://cnx.org/content/m16447/latest/\}.

7 Mwero, J. N. Abuodha, S. O. (2018) Heat of Hydration and Chemical Shrinkage Characteristics of Sugarcane-WasteFiber-Ash (SWFA), Blended Cement. Journal of Scientific and Research Publications, Volume 8, Issue 6, June 2018, 77 - 88 Neville, A. M. (1995). Properties of Concrete. Dorling Kindersley (India) Pvt. Ltd, $4^{\text {th }}$ Ed. 